Opinion

\title{
My innovation in cellular \& molecular medicine
}

\section{Opinion}

We are here to discuss to solve the problems of genetics related diseases by cellular and molecular medicines. As you know that study of genetics is very long process and day by day the problem of genetics deformity is increasing.

In my personal thought if mother and father having any kind of deficiency in the body and blood then the children gets one by one same kind of problems. In my personal experience if any person, Liver is affected by any injuries, infections, metabolic disorders or depress by any reason then the digestion of vitamins, A, D, C, K, Iron and any other substance not digest properly and not absorb properly. But person will not get any problem and if long time he or she not gets any sign and symptoms then they not go for treatment. Many people gets problems but they ignore it and many times Doctors also do not know the real cause of problems. Many times we can see the problems in children but not in mothers and fathers. If any person gets some problem then we are trying to solve the problems by substitutes and by substitute the problems will be disappear for some time but not cure and after some time it will be relapse.

For example: All over the World people are using vitamin $\mathrm{k}$ injection or a tablet for blood clot. It is for time being control but not for permanent cure. For this problem, my innovation is bile salt (colic acid) because it is tested by me. My Elder sister in law (Asha Rani Lal) w/o Vinod Stephen from Sugauli 845456 East Champaran Bihar India was suffering by blood clotting factor since child hood She have taken many injections and eaten many tablets but after some time the problem was same. But In 2003, I given her Bile juice and then the problem of blood clotting is solve naturally. Now she has no blood clotting problem since 15 years.

My next experience is in Genetics Disorders: My younger sister in low Ester Prasad w/o Vincent Prasad from Ngaphgrah New Delhi Both of them not suffering from any diseases or problems and they not
Volume 6 Issue I - 2019

Pramod Stephen

Independent Health, Wellness and Fitness Professional, India

Correspondence: Pramod Stephen, Independent Health, Wellness and Fitness Professional, India, Tel +919199646455, Email pramod_stephen@rediffmail.com

Received: August 06, 2018 | Published: January 29, 2019

feel any kind of disorders. They had two children both had digestive, cold and cough problems. First Girl (Mhima) died in the age of one and half years in 2000. 2nd son (Anos) sufferings from digestive, cold cough and other problems also his stool was always oily. All India Institute of medical sciences New Delhi Doctors diagnose cystic fibrosis and told that it is Genetic disorder. Doctors of AIIMS treated him by pancreatin and enzymes and other medicines. That time, I went Delhi in 2006 for some work and gave one, one dose of bile juice to ester and Vincent Prasad after some time ester conceives and gave a birth to a female child name (Angle) now she is 10 years old and now completely fit. But her elder brother died in the age of 10 years on September 24.2010.

So my advice is to all scientific community to study on bile juice and its benefits for mankind. My patent no. Is 834/kol/2007 I wrote a book "YOUR HEALTH IS IN YOUR MOUTH" to control diabetes, digestive system, genetics problems, obesity and other kind of metabolic disorders.

\section{Acknowledgment}

None.

\section{Conflicts of interest}

Author declares that there is no conflict of interest. 